\section{The Mesoproterozoic Stac Fada Member, NW Scotland: An impact origin confirmed but refined}

3

4

5

6

7

8

9

10

12

13

14

*Correspondence: gosinski@uwo.ca
Abbreviated title: Origin of the Stac Fada Member
G. R. Osinski ${ }^{1,2 *}$, L. Ferrière ${ }^{3}$, P. J. A. Hill ${ }^{1,2,4}$, A. R. Prave ${ }^{5}$, L. J. Preston ${ }^{6}$, A.

\section{Singleton $^{1,2}$ \& A. E. Pickersgill ${ }^{7}$}

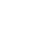

${ }^{1}$ Department of Earth Sciences, University of Western Ontario, London, Ontario, N6A 5B7,

Canada.

${ }^{2}$ Institute for Earth and Space Exploration, University of Western Ontario, London, Ontario, N6A 5B7, Canada.

${ }^{3}$ Natural History Museum, Burgring 7, A-1010 Vienna, Austria.

${ }^{4}$ Department of Earth and Atmospheric Sciences, University of Alberta, Edmonton, Alberta T6G 2E3, Canada

${ }^{5}$ School of Earth and Environmental Sciences, University of St Andrews, St Andrews, Fife,

KY16 9AL, Scotland

${ }^{6}$ Department of Earth Sciences, The Natural History Museum, Cromwell Road, London, SW7 5BD, United Kingdom

${ }^{7}$ School of Geographical and Earth Sciences, University of Glasgow, Glasgow, G12 8QQ, United Kingdom 
27 Abstract: The origin of the Stac Fada Member has been debated for decades with several early hypotheses being proposed, but all invoking some connection to volcanic activity. In 2008, the discovery of shocked quartz led to the hypothesis that the Stac Fada Member represents part the continuous ejecta blanket of a meteorite impact crater, the location of

31 which was, and still remains, unknown. In this contribution, we confirm the presence of

32 shock-metamorphosed and -melted material in the Stac Fada Member; however, we also show

33 that the properties of the Stac Fada Member are unlike any other confirmed and well

34 documented proximal impact ejecta deposits on Earth. Instead, the properties of the Stac Fada

35 Member are most similar to the Onaping Formation of the Sudbury impact structure (Canada)

36 and impact melt-bearing breccias from the Chicxulub impact structure (Mexico). We thus

37 propose that, like the Sudbury and Chicxulub deposits, melt-fuel-coolant interactions - akin to

38 what occurs during phreatomagmatic volcanic eruptions - played a fundamental role in the

39 origin of the Stac Fada Member. We conclude that these rocks are not primary impact ejecta

40 but instead were deposited beyond the extent of the continuous ejecta blanket as high-energy

41 ground-hugging sediment gravity flows. 


\section{Introduction}

Over the past several decades, there has been a growing awareness of the importance of impact cratering as an important and, indeed, fundamental planetary geological process (Melosh 1989; Osinski \& Pierazzo 2012; Grieve 2017). The ever increasing exploration of

Solar System bodies by robotic spacecraft has returned a wealth of data on meteorite impact craters; however, the impact cratering record on Earth remains critical and necessary for ground-truthing planetary observations due to the ability to conduct fieldwork, detailed geophysical surveys, and to obtain samples with known context. The number of confirmed meteorite impact craters on Earth stands at approximately 200 (Osinski \& Grieve 2019; see also www.impactearth.com for an up-to-date inventory). It is notable that there remains no confirmed impact crater in the British Isles, although the existence of both distal and proximal impact ejecta layers have been proposed from SW England (Walkden et al. 2002) and the Scottish Highlands (Amor et al. 2008; Drake et al. 2017). Of these, the Stac Fada Member, part of the Torridonian Supergroup, has received most attention to date and is the focus of this study.

The $\sim 1.2-1.0$ Ga Torridonian Supergroup of NW Scotland comprises a succession of mostly reddish-brown sandstones as much as $8 \mathrm{~km}$ thick that rest unconformably on Neoarchaean rocks of the Lewisian gneiss complex (Stewart 2002). These distinctive rocks dominate the landscape of this region, forming prominent mountains. It is divided, from oldest to youngest, into the Stoer, Sleat and Torridon Groups. The Stac Fada Member is part of the Stoer Group (Fig. 1) and was initially thought to be volcanic in origin; ideas varied from an ash flow deposit related to hydroclastic eruptions (Lawson 1973), a hot mudflow generated by magma intruded into wet sediment (Sanders \& Johnston 1989), to a volcanic debris flow (Stewart 2002; Young 2002). In 2008, Amor et al. (2008) proposed that the Stac 
Fada Member was an impactite (i.e., a rock affected by hypervelocity impact resulting from the collision of planetary bodies; Stöffler \& Grieve 2007) called "suevite", forming the proximal ejecta blanket of a meteorite impact structure. These conclusions were based on the presence of shocked quartz grains (and biotite with kink bands, which are not, however, diagnostic of shock; French \& Koeberl, 2010), chromium isotopes and elevated platinum group metal and siderophile element abundances. More recently, these authors referred to the Stac Fada Member as an impact melt rock (Amor et al. 2019). The discovery of reidite $\left(\mathrm{ZrSiO}_{4}\right)$ provided further evidence of an impact origin (Reddy et al. 2015). The location of the source crater remains unresolved: one suggestion is The Minch (Fig. 1), northwest of the outcrop belt (Amor et al. 2019), and the other is the Lairg Gravity Low (Fig. 1) (Simms 2015; Simms \& Ernstson 2019), which, if correct, has significant implications for the deep crustal structure of northern Scotland (Butler \& Alsop 2019; Simms 2019; Simms \& Ernstson 2019). The motivation for our study was three-fold. Firstly, continuous impact ejecta blankets are rare on Earth due to their rapid erosion hence the Stac Fada Member could provide insight into ejecta emplacement on terrestrial planets (Branney \& Brown 2011; Osinski et al. 2011). Secondly, very low amounts of shocked material combined with high glass abundance (Amor et al. 2008) and high degree of sorting are at odds with observations of other known impact ejecta deposits (Osinski et al. 2011, 2012) and this deserves explanation. Thirdly, the mechanism of emplacement of the Stac Fada Member remains a subject of debate. Here we provide additional documentation of shock features, further reinforcing the impact origin of material contained within the Stac Fada rocks. We offer, though, an alternative hypothesis for their genesis, one based on recent understanding of impactites associated with the Sudbury (Canada) and Chixulub (Mexico) impact structures, both of whose origins are attributed to molten-fuel-coolant interaction analogous to what occurs during phreatomagmatic volcanic eruptions (Grieve et al. 2010; Osinski et al. 2020). 
Geological setting of the Stac Fada Member

The Mesoproterozoic Stoer Group defines a patchily preserved outcrop belt extending for ca. $50 \mathrm{~km}$ along the NW coastal area of Scotland (Fig. 1). It is the oldest nonmetamorphosed sedimentary rock unit in Britain, consisting predominantly of fluvial sandstone as much as $2.5 \mathrm{~km}$ thick and divided into the Clachtoll, Bay of Stoer, and Meall Dearg formations (Stewart 2002). The Bay of Stoer Formation is further divided into the Stac Fada and Poll a'Mhuilt members. The lithostratigraphy follows that of Stewart (2002) as amended by Simms (2015). Potassium feldspar veins of presumed hydrothermal origin in the Stac Fada Member yield an ${ }^{40} \mathrm{Ar} /{ }^{39} \mathrm{Ar}$ age of $1177 \pm 5 \mathrm{Ma}$ (Parnell et al. 2011). The Stac Fada Member contains accretionary lapilli and abundant chloritized shards interpreted as former glass fragments. The latter two features are unique to the Stac Fada Member within the Torridonian succession and are key components in assessing its origin.

108 Also important to note is that the overlying Poll a'Mhuilt Member was originally thought to

109 be lacustrine (Stewart 2002), potentially formed due to drainage disruption by the effects of 110 the impact (Amor et al. 2008; Simms 2015), but recently has been shown, in part, to be 111 estuarine in origin (Stüeken et al. 2017).

\section{Samples and methods}

Fieldwork was carried out to investigate the Stac Fada Member on multiple occasions

116 from 2008 to 2016 . This unit was studied and sampled at 5 localities, with samples being

117 collected with a chisel and rock hammer (Fig. 1). Optical microscopy was performed on

118 polished thin sections from 46 samples using an optical microscope at up to $200 \mathrm{x}$ 
magnification combined with a four-axis universal-stage (U-stage) (Emmons 1943). The entire area of each thin section was examined and all quartz grain properties recorded, i.e. unshocked, shocked with planar fractures (PF), shocked with planar deformation features (PDF), number of sets of PFs and PDFs, presence of PDF decoration, and the overall appearance. The exact position of each shocked quartz grain was noted on a thin section map and crystallographic orientations of PF and PDF sets in shocked quartz grains were measured using the U-stage microscope, following the methods described in the literature (e.g. PDF sets was done with the Automated Numerical Index Executor (ANIE) program (using the average value of measurements and a $5^{\circ}$ error; Huber et al. 2011).

Quantitative analyses and investigation of micro-textures were carried out using both back-scattered electron (BSE) imagery and wavelength dispersive X-ray (WDS) techniques on a JEOL JXA-8900 L electron microprobe. Electron microprobe data were reduced using ZAF procedures incorporated into the operating system. Semi-automatic digital image analysis was conducted to quantify the geometry of clasts

134 in hand samples to compare them to previously collected and published data on hand samples 135 of other glass-bearing breccias from confirmed and well-studied impact ejecta deposits at the 136 Ries (Germany) and Mistastin Lake (Canada) impact structures, together with similar glass137 bearing breccias from the Sudbury (Canada; i.e., the Onaping Formation) and Chicxulub 138 (Mexico) impact structures (Osinski et al. 2016, 2020; Hill et al. 2020). Following the 139 methods of Chanou et al. (2014), particles of interest (POI) (i.e., vitric particles) were 140 segmented and measured using the National Instituted of Health's digital imaging freeware, 141 ImageJ. RGB images were contrasted so that vitric particles and associated features could be

142 binned. If the contrast between the POI and the background was high enough, POIs were 143 segmented by splitting the three colour channels and thresholding the resulting 8-bit grayscale 
144 image. If the original image contrast was not high enough, background subtraction allowed

145 for isolation of clasts prior to splitting channels and segmenting the 8-bit grayscale image.

146 Following segmentation of the POIs, the 8-bit grayscale images were manually corrected for

147 any lighting, deformation, or image artefacts that could have been incorrectly segmented.

148 Particle analysis was then conducted allowing for determination of area, perimeter, area

149 fraction, shape descriptors and fractal dimension.

Field relations and petrography the descriptive term "melt-bearing breccia" for the Stac Fada Member to reflect the fact that it contains material that was formerly molten and that overall, it is a rock that contains angular clasts $>2 \mathrm{~mm}$ in diameter surrounded by a finer grained matrix; a caveat is that there are small areas where, in outcrop and hand sample, the Stac Fada Member could be classified as a sandstone. We also use the term "vitric" to describe the green clasts that were originally glass but are now completely devitrified and altered, although original morphologies are well

160 preserved. Bay of Stoer. This is the type locality of the Stac Fada Member. There, melt-bearing

162 breccia occurs in four main units (Young 2002), with the lower units resting sharply on and

163 interbedded with sandstone of the Bay of Stoer Formation and containing several large (up to $164 \sim 14 \mathrm{~m}$ long), tabular rafts of Bay-of-Stoer sandstone (Fig. 2). The basal unit (SF1 of Young 165 (2002)) is up to 3.2 m thick, sits sharply on underlying sandstone, and consists of a thin basal melt-free pebbly sandstone that grades upward over $\sim 10 \mathrm{~cm}$ into typical vitric-bearing melt

167 breccia. At low tide, it can be seen that the western contact of this basal unit is a fault, leading 168 to the interpretation by some workers (e.g., Young 2002)) that this is not a separate layer but 
rather a faulted offset of the main uppermost layer described below. We could not confirm this and the lack of accretionary lapilli and fluid escape pipes that are seen in SF4 (see below)

171 suggests that this may be a separate unit offset by an unknown amount from the other units.

172 The next two units are wedged-shaped: the first (SF2) is $\sim 1.5 \mathrm{~m}$ thick and the second (SF3) is

173 a few cm to dm-thick; both taper and pinch-out towards the northern end of the outcrop (a

174 distance of 10-15 m). Young (2002) considered these as discrete units but our observations

175 suggest they are apophyses extending from the overlying unit. In other words, the three main

176 Stac Fada Member units are continuous with each other (cf., Amor et al. 2008, 2019; Stewart 177 2002).

178 The uppermost melt-bearing breccia unit (SF4 of Young, 2002) averages $\sim 12 \mathrm{~m}$ in 179 thickness (Figs. 2a,b). This unit is typified by vitric clasts, $<0.1$ to $\sim 1 \mathrm{~cm}$ across (Fig. 2c) and 180 contains rounded to sub-rounded clasts of gneiss up to $\sim 50 \mathrm{~cm}$ across (Fig. $2 \mathrm{~d}$ ). It has an 181 erosional base and contains large (up to $\sim 14 \mathrm{~m}$ long) sandstone clasts near the base (Figs.

182 2a,b). These sandstone clasts are typically planar with shape controlled by the bedding; the 183 sandstones appear to all be locally derived. Overall, this main Stac Fada Member unit appears 184 massive, although crude indistinct bedding on the $\mathrm{mm}$ - to $\mathrm{cm}$-scale is discernable towards the 185 top and base; this bedding is much easier to see on polished hand specimens than in the field.

186 Sub-vertical, honeycomb-like structures (fluid escape pipes of Amor et al. 2008 and Parnell et 187 al. 2011) filled with authigenic feldspar are present throughout this unit. Rounded 188 accretionary lapilli $(\sim 2-6 \mathrm{~mm}$ diameter; average $\sim 2 \mathrm{~mm})$ are dispersed through the 189 uppermost $3 \mathrm{~m}$ but are concentrated in discontinuous lenses near the top of the unit. The Stac

190 Fada Member is overlain sharply by several metres of channelled sandstone, identical to the 191 underlying Bay of Stoer Group (see Fig. 1 of Stüeken et al. 2017). The sandstones contain 192 reworked clasts of impact melt-bearing breccia and accretionary lapilli and the contact with 193 the Stac Fada melt-bearing breccia locally shows deep erosive scours into the Stac Fada 
194 breccia (Fig. 2e). The sandstones pass upward over a few metres into grey and red mudstones 195 of the Poll a'Mhuilt Member.

196 In hand specimen and thin section, the vitric particles are dispersed in a clay to sand-

197 sized matrix and all are altered (Figs. 2c, 3a,b, 4). Image analysis of four samples delineated 1986,124 vitric particles with mean size of $0.2-0.4 \mathrm{~mm}$ with textures from shard-like and vesicle199 free to vesicular with flow textures (Figs. 4a-c). Vesicles are generally elongate and many are 200 infilled with secondary minerals (Fig. 4c). It is notable that schlieren and quench crystallites 201 typical for impact glasses (Stöffler 1984) - are lacking in the samples we have studied (Table 202 1). Some vitric clasts contain undigested quartz and, more rarely, feldspar grains. Rubh' a' Choin, Enard Bay. The Stac Fada Member is thickest ( $20 \mathrm{~m})$ at this

204 locality and comprises a single unit. The bulk of the member at this location is the 205 characteristic glass-bearing breccia similar to the main upper unit at the Bay of Stoer. The 206 major difference is towards the top where the upper 2-3 $\mathrm{m}$ is dominated by accretionary 207 lapilli (Figs. 2e, 3c, 4d); fluid escape pipes are also notably absent. Layering on the mm to 208 dm-scale is occasionally present (cf., Gracie \& Stewart 1967). It occurs above a variably thick 209 interval of interbedded sandstone and sedimentary breccia of the Clachtoll Formation (Fig. 2f) 210 (e.g., Stewart 2002). Amor et al. (2019) interpreted these underlying rocks to be a 211 consequence of ballistic fragmentation along the outer layer of a collapsing ejecta blanket.

212 However, careful inspection shows that these rocks are no different to the Clachtoll Formation 213 elsewhere hence are most parsimoniously and objectively interpreted as material derived by 214 normal erosional processes that formed the irregular palaeotopography observed everywhere 215 along the contact of the Stoer Group and Lewisian gneiss complex.

216 Outcrops elsewhere. The remaining outcrop localities of the Stac Fada Member south 217 of Enard Bay are mostly thinner $(<10 \mathrm{~m}$ thick) and their field and petrographic characteristics 218 have been described in detail by Simms (2015) and, although differences exist between 
219 localities, the general character of the Stac Fada makes it recognisable from location to

220 location. A notable exception is the $\sim 7 \mathrm{~m}$ thick outcrop at Stattic Point in which accretionary

221 lapilli are absent but vitric clasts are at the highest concentrations and exhibit the largest sizes,

222 as much as $\sim 15 \mathrm{~cm}$ across (cf., Amor et al. 2008; 2019). This outcrop also displays distinctive

223 curved fractures that penetrate $\sim 1 \mathrm{~m}$ into the outcrop and that do not continue into the

224 overlying sandstone of the Poll a'Mhuilt Member. Simms (2015) interprets these features as

225 ogive fractures or synsedimentary shear surfaces that develop on or near the surface of

226 mudflows and other slowly moving viscous materials.

Textural image analysis. The Stac Fada Member is often described as being poorly sorted. However, that is only relative to the encasing sandstones. More importantly for this study is how the Stac Fada Member compares to glass-bearing breccias from other wellstudied impact structures where the stratigraphic context and setting with respect to the host crater is known. Thus, using the semi-automated image analysis methodology of Chanou et al. (2014), we quantified the degree of sorting of the Stac Fada breccias with respect to a calibrated sorting scale and compared this to data from other glass-bearing impact breccias.

234 Specifically, we compared the Stac Fada Member to the two best-preserved and exposed 235 examples of glass-bearing proximal ejecta deposits on Earth (the Ries (Engelhardt 1990) and 236 Mistastin (Mader \& Osinski 2018) impact structures), together with glass-bearing breccias 237 from the Onaping Formation from the Sudbury impact structure (Grieve et al. 2010) and the 238 Chicxulub impact structure (Osinski et al. 2020) (Figs. 5, 6). These results clearly show that 239 the Stac Fada Member is markedly different to the Ries and Mistastin ejecta deposits, in that it 240 is moderately to very well sorted, but displays similar properties to the Sudbury and 241 Chicxulub glass-bearing breccias. 
Due to the high pressures generated during the impact cratering process (up to and exceeding $100 \mathrm{GPa}$ ), rocks and minerals can undergo a series of transformations and produce a range of characteristic and diagnostic shock metamorphic effects (see French \& Koeberl 2010, for a review). The presence of planar deformation features (PDFs) in quartz provides unequivocal diagnostic evidence for meteorite impact events (French \& Koeberl 2010) and, as 250 such, was a high priority during our investigations. It is notable that we found no evidence of shock metamorphism in 30 clasts of shocked gneiss that we investigated; rather, shock effects are restricted to mineral clasts as described below. The absence of shock-metamorphic effects in lithic clasts is in stark contrast to impact melt-bearing ejecta from other impact craters, such as the Mistastin and Ries impact structures, but is in keeping with observations of the Onaping Formation from the Sudbury impact structure and the melt-bearing breccias from the Chicxulub impact structure (Table 1).

In terms of the shock mineral grains, compared to other impact craters, the Stac Fada Member has a minimal amount of shocked quartz (Table 1). What shocked quartz is present, though, is varied (Table 2) and includes undulose extinction, PFs and/or PDFs, mosaicism and

260 a few grains with patches of micrometre-scale fluid inclusions and a greyish-brown appearance (Fig. 7a), described by some workers as "toasted" (Whitehead et al. 2002; Ferrière et al. 2009b). The maximum number of shocked quartz grains with PFs and/or PDFs in any one thin section was eight. Occasionally, PFs and PDFs occur together in the same quartz

264 grain. Typically, quartz grains contain one or two sets of PDFs (Figs. 7b-d), and more rarely 265 three (Fig. 7e) or four sets were observed under the U-stage (Table 2). The PDFs are 266 frequently decorated with numerous tiny fluid inclusions, and, thus, are more easily detected 267 as compared to the less visible, non-decorated PDFs. It can be explained in part that additional 268 PDF sets, not visible under the optical microscope, were detected (and measured) under the 
U-stage microscope (Fig. 8). Similar observations were reported in the detailed study of

270 shocked quartz from the Bosumtwi crater (Ghana) by Ferrière et al. (2008).

Because specific crystallographic orientations of PDFs in quartz grains are formed at

272 different shock pressures (see e.g., Hörz 1968; Müller \& Défourneaux 1968; Huffman \& Reimold 1996), crystallographic orientations of PDF sets can be used to constrain the peak shock pressure that these grains have experienced. The crystallographic orientations of $90 \mathrm{PF}$ and PDF sets in 59 shocked quartz grains from 18 thin sections were measured with the Ustage. Data in absolute frequency $\%$ are reported in Table 3 and absolute frequency $\%$ of indexed PDF sets versus angle between the c-axis and poles to PDF planes is shown in Figure 8. A large proportion, 63 absolute frequency percent, of all the poles to the PDF planes measured are oriented parallel to the $\omega\{10 \overline{1} 3\}$ orientation. In addition, about 14 absolute frequency percent of the measured PDF sets are parallel to the $\{10 \overline{1} 4\}$ orientation and also to the $\pi\{10 \overline{1} 2\}$ orientation, whereas, planes parallel to the c(0001), $\{21 \overline{3} 1\}$, and $\{2 \overline{4} \overline{1} 1\}$ orientations are also present (Table 3; Fig. 8), but in somewhat lower proportions. It should be noted that because it is impossible to uniquely distinguish between $\{10 \overline{1} 4\}$ and $\{10 \overline{1} 3\}$ orientations using the U-stage when the angle between c-axis and poles to PDF is about 18$23^{\circ}$, all measured planes that fall into the overlap zone between $\{10 \overline{1} 4\}$ and $\{10 \overline{1} 3\}$ orientations are considered as $\{10 \overline{1} 3\}$ orientations for the purpose of our U-stage analysis, as recommended by Ferrière et al. (2009a).

Only two quartz grains with PDFs were found in vitric clasts from two separate samples (Tables 1,2), one had two PDF sets with $\{10 \overline{1} 3\}$ orientations and the other had one highly decorated PDF set with $\{10 \overline{1} 4\}$ orientation. Two shocked quartz grains were found in lapilli in one sample with one PF set orientated at $\{10 \overline{1} 0\}$ and another at $\{10 \overline{1} 3\}$. A few feldspar grains were observed that were highly fractured, but these, too, did not display shock-related features. Kink bands were observed in muscovite and in chlorite grains. However, kink bands 
294 in micas are common in metamorphosed and deformed rocks (e.g., Lewisian gneiss) and 295 cannot be used as criteria for an impact origin.

\section{Discussion}

\section{Confirming the presence of shocked material in the Stac Fada Member}

During meteorite impact events, pressures and temperatures are sufficient to vaporize, melt, and/or metamorphose a substantial volume of the target sequence (e.g., French \& Koeberl 2010; Osinski et al. 2018). A variety of characteristic shock metamorphic indicators are produced, such as shatter cones, PDFs, and diaplectic glasses (French \& Koeberl 2010; Ferrière \& Osinski 2012). Amor et al. (2008) identified PDFs in 25 quartz grains from 9 thin sections. Our observations from 46 thin sections confirm the presence of PDFs in quartz. We documented 78 PDF sets in 48 quartz grains (Table 2), which is a notably lower PDF-planeto-grain ratio, 1.63, than the 2.36 reported by Amor et al. (2008). This difference of results is not surprising, as Amor et al. (2008) measured only 25 quartz grains in nine thin sections as

310 compared to the 78 PDF sets in 48 quartz grains in this study. In addition, the U-stage results of Amor et al. (2008) left with 31\% of PDF sets unindexed, raising questions about how representative their results are (Ferrière et al. 2009a).

Based on our U-stage results, PDF orientations parallel to $\{10 \overline{1} 3\}$, like those measured

314 in our work, require shock pressures between 12-20 GPa (Stöffler \& Langenhorst 1994), with 315 some workers suggesting a minimum required of $16 \mathrm{GPa}$ (Hörz 1968). The presence of vitric 316 clasts suggests that pressures could have been greater than $\sim 50 \mathrm{GPa}$ given that the impact was 317 in hard and/or crystalline rocks (Stöffler 1972, 1984; Osinski et al. 2018). Thus, our results 318 corroborate the findings of Amor et al. (2008) and Reddy et al. (2015) and further confirm 
that the Stac Fada Member contains material derived from an impact event. However, the

320 amount of shocked material in the Stac Fada Member is extremely low compared to other

321 impact ejecta deposits (Table 1) (see also the recent detrital zircon and apatite study by Kenny 322 et al. (2019)), which we discuss further below.

6.2. The Stac Fada Member: a continuous impact ejecta deposit?

325

Impact ejecta deposits can be defined as target materials transported beyond the rim of the transient cavity (Osinski et al. 2011). It is widely accepted that the initial emplacement of a continuous ejecta blanket around impact craters is via ballistic sedimentation (Oberbeck 1975) in which ejected material follows a nearly parabolic flight path before striking the surface at some percentage of the velocity that it possessed when ejected. Upon landing, this primary ejecta continues to flow across the surface, generating considerable erosion and incorporation of local material (i.e., "secondary ejecta"), thereby modifying the region surrounding the host crater (Oberbeck 1975; Hörz 1982). Acknowledging that the target rock influences the final characteristics and radial extent of ejecta blankets (e.g., Oberbeck 1975; Hörz 1982; Barlow 2005; Osinski et al. 2011), the preserved remnants of well-studied continuous ejecta blankets (e.g., the Bunte Breccia at the Ries impact structure and Meteor Crater ejecta deposits) exhibit three common features: (i) abundant material shocked to low pressures, (ii) a dearth of high shocked and shock-melted material (i.e. vitric clasts), and (iii) very poor sorting with blocks reaching 100s of m to km in size (Shoemaker 1963; Hörz 1982; Hörz et al. 1983). While the low amount of shocked material is a common trait, it is clear that the Stac Fada Member bears little resemblance to the continuous ejecta blankets of simple (e.g., Meteor Crater) or complex (e.g., Ries) impact structures. Most critical is the overall well sorted nature and the preponderance of vitric clasts in the Stac Fada Member. Thus, ballistic 
emplacement can be ruled out for its emplacement (cf., Branney \& Brown, 2011). Regarding

345 the idea that isolated blocks of gneiss in sandstones immediately underlying the Stac Fada

346 Member at some locations (e.g., Second Coast) (Simms 2015), while we do not see evidence

347 for disturbance of the surrounding sediments - which would be expected due to the high

348 velocities of spall blocks (Oberbeck 1975; Melosh 1989) - we cannot rule out the possibility

349 that these are isolated crater-derived blocks ejected and transported for considerable distances

350 beyond the continuous ejecta blanket.

At most impact craters on Earth with preserved ejecta deposits, the continuous ejecta

352 blanket is overlain by a second patchy layer of ejecta (Osinski et al. 2011). The properties of

353 these overlying deposits are fundamentally different to the underlying continuous ejecta

354 blankets. These overlying deposits are melt rich (being impact melt rocks and/or melt-bearing

355 breccias, often termed suevite), contain a much higher proportion of shocked material, are still

356 poorly sorted but do not contain clasts on the $10 \mathrm{~s} \mathrm{~m}$ to $\mathrm{km}$-scale, and are derived from deeper

357 in the target stratigraphy (Osinski et al. 2011, 2012) (Table 1).

358 As outlined in Table 1 and shown in Figures 5 and 6, the Stac Fada Member also bears

359 little to no resemblance to the melt-bearing ejecta deposits at the Ries and Mistastin impact

360 structures - the two best-preserved examples on Earth - or other craters as described in

361 Osinski et al. (2011). While these ejecta deposits contain more melt than continuous ejecta

362 blankets like the Bunte Breccia at the Ries structure, and similar to the Stac Fada Member,

363 there are several important differences. Most importantly, the Stac Fada Member is

364 moderately to very well sorted, contains very few shocked mineral clasts, no shocked lithic

365 clasts, is dominated by vitric clasts rather than lithic clasts, and possesses internal layering

366 and grading, all properties that fundamentally differentiate this unit from all other documented

367 melt-bearing ejecta deposits on Earth (Table 1; Figs. 5, 6). In summary, in contrast to previous

368 suggestions (Amor et al. 2008; Branney \& Brown 2011), the properties of the Stac Fada 
Member are unlike any other confirmed proximal ejecta deposits on Earth. But what about

$370 \quad$ Mars?

Several previous workers have drawn analogies between the Stac Fada Member and

372 impact ejecta deposits on Mars (Amor et al. 2008; Simms 2015). This analogy was largely

373 based on invoking an impact into volatile-rich target rocks. Unfortunately, the ancient and

374 eroded nature of the Stac Fada Member does not allow for any quantitative comparision to be

375 made with martian ejecta deposits via satellite imagery - such as has been made for the Ries

376 impact structure for example (Sturm et al. 2013) - and the lack of samples or surface-based

377 imagery from rovers or landers from the latter also precludes any direct comparision.

378 However, based on a combination of theoretical and observational considerations, regardless

379 of the complicating factors due to volatiles and/or an atmosphere on Mars (Barlow 2005), it is

380 still predicted that single layer ejecta craters are initially emplaced ballistically (Osinski 2006;

381 Oberbeck 2009), which as discussed above, appears incompatible with the properties of the

382 Stac Fada Member.

\subsection{Origin of the Stac Fada Member}

Unlike the stark differences between the Stac Fada Member and continuous impact ejecta deposits, it shares many striking similarities with impact melt-bearing breccias of the Onaping Formation (Sudbury) and those at the Chicxulub impact structure are striking (Table 1; Figs. 5, 6). These include the predominance of vitric particles, low abundance of shocked material, overall well-sorted textures and presence of internal layering. Long thought to be a fallback breccia (French 1967), the Onaping Formation has been

392 reinterpreted as the product of melt-fuel-coolant interactions (MFCI; Grieve et al. 2010), a 393 process similar to what occurs during phreatomagmatic volcanic eruptions or hydrovolcanism. 
The products of volcanic MFCI activity are layered, fine-grained (fine to medium ash size),

395 well sorted, and glass is the most abundant clastic component (Büttner et al. 2002). In this

396 scenario, it is envisaged that seawater entered the Sudbury crater soon after the impact and

397 encountered the superheated impact melt sheet (i.e., the proto-Sudbury Igneous Complex). A

398 vapour film was created that would have expanded and collapsed rapidly as seawater came

399 into direct contact with the melt to generate repetitive melt quenching and fragmentation

400 (Wohletz 1983; Büttner et al. 2002; Grieve et al. 2010; Wohletz et al. 2013). The MFCI

401 model is consistent with the fact that Sudbury occurred in a marine setting and has been tested

402 via comparison with volcanic MFCI deposits (Osinski et al. 2016). Chicxulub impact melt-

403 bearing breccias share many of the same attributes as the Onaping Formation and an MFCI

404 origin for those has also been recently proposed (Osinski et al. 2020). It is worth mentioning

405 that various origins have been proposed for suevite at the Ries impact structure, including the

406 suggestion that MFCI played a role (Artemieva et al. 2013; Stöffler et al. 2013). However, as

407 is clear in Table 1 and as discussed by (Osinski et al. 2016) and Siegert et al. (2017), the Ries

408 suevites bear little to no resemblance to volcanic MFCI deposits, or the aforementioned

409 Sudbury and Chicxulub deposits, and thus do not share the same origin.

410 Intriguingly, the Stac Fada Member contains many of the features of the Onaping

411 Formation and Chicxulub impact melt-bearing breccias (Table 1), which hints strongly at

412 causality and an origin involving MFCI. There are some differences, but these are subtle. For

413 example, the vitric particles in the Stac Fada Member display a wider range of shapes and

414 higher abundance of vesicles and clastic material is also more abundant compared to Sudbury

415 or Chicxulub, but such differences are readily explained by variations of water-to-melt-mass

416 ratios (e.g., Wohletz 1983). What is more central to the discussion is palaeogeography. Both

417 the Onaping and Chicxulub deposits occur in the interior of large $200-250 \mathrm{~km}$ diameter size

418 craters located on what were shallow-marine shelves at the time of impact; no crater or melt 
material of comparable scale is known for the Stac Fada Member, which also does not sit inside a crater (as far as we know). Hence, we propose a modified MFCI scenario. rests on a succession of fluvial sandstones variably many tens to several hundreds of metres thick; (ii) shocked quartz is predominantly in the form of mineral clasts - consistent with a sandstone protolith - and gneiss clasts are unshocked, evidence that the impact likely breached the supracrustal cover sequence but not the crustal rocks; and (iii) fluvial deposition resumed following the impact, as evident by the presence of sandstones identical to those of the Bay of Stoer Formation that reoccur between the top of the Stac Fada Member and the Poll a'Mhuilt estuarine mudstones. Further, given that the Poll a'Mhuilt Member contains evidence for marine influences on deposition (Stüeken et al. 2017), shallow-marine settings would have been nearby. that the impact was into volatile-rich sediments. However, the Stac Fada is encased by sandstone bodies that are identical to those that typify the underlying Bay-of-Stoer Formation

434 (according to the revised stratigraphy of Simms 2015) and not, as suggested by Amor et al. 435 (2008), the mudstones of the Poll a'Mhuilt. Hence, unlike their scenario, it is far more in 436 keeping with the stratigraphic observations that the impact was into the river systems and 437 water-laden sandy sediments that are now preserved as the Bay of Stoer Formation rather than 438 the mudstones of the Poll a'Mhuilt. Hence, there would have been abundant water to drive 439 MFCI within the host crater and to transport this melt and other crater-derived material well 440 beyond the host crater. Indeed, using the Oruanui Formation of New Zealand - the product of 441 a 27 ka phreatomagmatic eruption from the Taupo Volcanic Zone - as an example, MFCI 442 deposits can extend several hundred $\mathrm{km}$ from their source and cover thousands of square 443 kilometres (Self \& Sparks 1978). This dispersal by such energetic interactions thus accounts 
444 for the high amount of melt but also for the low amount of shocked material in the Stac Fada 445 Member.

446 In keeping with the presence of sedimentary structures and properties in the Stac Fada 447 Member similar to debris flows (e.g., Stewart 2002; Young 2002), mud flows (Simms 2015), 448 and density currents (Branney \& Brown 2011), we envisage that its sedimentation would have 449 been outwith the extent of the continuous ballistically-emplaced ejecta blanket as high-energy 450 ground-hugging sediment gravity flows. Such a scenario is consistent with the careful 451 sedimentological work of Stewart (2002) and Young (2002) modified by the knowledge that 452 the melt component was generated by hypervelocity impact rather than volcanism. Whether 453 the emplacement of these flows was triggered by the deposition of impact ejecta elsewhere, 454 the MFCI process itself, or due to seismic shaking initiated by the impact, remains to be 455 determined. Whatever the trigger, it is clear that the emplacement of the Stac Fada Member 456 was rapid given the restriction of accretionary lapilli and dust pellets - which would have 457 formed in the ejecta plume (Branney \& Brown 2011; Johnson \& Melosh 2014) - in the upper 458 parts of the sequence. As for the location of the impact crater, we remain agnostic and await 459 with the hope that additional evidence will be found to determine its position (assuming that it 460 is preserved).

\section{Concluding remarks}

465 Scotland and, unsurprisingly, has been the subject of much debate over the past 50 years or so. A significant advancement in our understanding of this unit was the discovery of shocked quartz grains and other isotopic and geochemical evidence for an impact origin by Amor et al.

468 (2008). In this contribution we have confirmed the presence of shocked material in the Stac 
Fada Member but highlight several properties that are clearly different to other known and well characterized impact ejecta deposits. As such, the Stac Fada Member should not be used

471 to infer emplacement of impact ejecta in general (Branney \& Brown 2011). We offer a

472 modified impact model involving MFCI based on the similarities of the Stac Fada Member

473 with well-sorted, glass-rich breccias from the Sudbury and Chicxulub impact structures and

474 with volcanic MFCI deposits formed during phreatomagmatic volcanic eruptions.

475 In closing, we note that the Stac Fada Member deposits are not accounted for in the

476 current proposed classification scheme for impactites (Stöffler \& Grieve 2007). They are

477 unquestionably not impact melt rocks as proposed by (Amor et al. 2019), which by definition

478 possess an igneous groundmass (e.g., Dence 1971; Stöffler \& Grieve 2007; Osinski et al.

479 2018). We have also shown that Stac Fada Member breccias bear little resemblance to

480 traditional "suevite" found at craters such as the Ries and Mistastin impact structures. Instead,

481 the Stac Fada Member joins the Onaping Formation at the Sudbury impact structure and the

482 melt-bearing breccias at Chicxulub in representing a new class of impact product akin to

483 volcaniclastic rocks (cf., Osinski et al. 2020).

485 Acknowledgements This paper is dedicated to Grant Young who sadly passed away in 486 August 2020. Grant was a long standing member of the Department of Earth Sciences at 487 Western. During his long career he made numerous important contributions to understanding 488 the geology of the Scottish Highlands, including the Stac Fada Member. We also thank 489 Richard A. F. Grieve for discussions on this topic, Stephen Wood for preparation of the thin 490 sections, and John Ferries for his companionship in the field. Michael Simms, Ken Amor, and 491 an anonymous reviewer are thanked for their thoughtful and constructive reviews on this 492 manuscript. 
494 Funding Funding to GRO. from the Natural Sciences and Engineering Research Council of

495 Canada (NSERC) Discovery Grant program and the Canadian Space Agency (CSA) Canadian

496 Analogue Research Network and Field Investigation programs is gratefully acknowledged.

497 Part of LF's work was supported by the Department of Foreign Affairs and International

498 Trade (DFAIT), Government of Canada.

499

500 Author contributions GRO: conceptualization (lead), formal analysis (lead), funding 501 acquisition (lead), investigation (lead), methodology (lead), project administration (lead), 502 resources (lead), supervision (lead), validation (lead), visualization (lead), writing - original 503 draft (lead), writing - review and editing (lead). LF: formal analysis (supporting),

504 investigation (supporting), methodology (supporting), validation (supporting), visualization 505 (supporting), writing - original draft (supporting), writing - review and editing (supporting).

506 PJAH: formal analysis (supporting), investigation (supporting), methodology (supporting), 507 validation (supporting), visualization (supporting), writing - review and editing (supporting). 508 ARP: investigation (supporting), writing - review and editing (supporting). LJP: investigation 509 (supporting), writing - review and editing (supporting). AS: investigation (supporting), 510 writing - review and editing (supporting). AEP: investigation (supporting), writing - review 511 and editing (supporting).

513 Data Access Statement Most data generated or analysed during this study are included in 514 this published article. Additional raw data are available from the corresponding author on 515 reasonable request. 


\section{References}

Ames, D.E., Golightly, J.P., Lightfoot, P.C. \& Gibson, H.L. 2002. Vitric compositions in the Onaping Formation and their relationship to the Sudbury Igneous Complex, Sudbury Structure. Economic Geology, 97, 1541-1562.

Ames, D.E., Davidson, A. \& Wodicka, N. 2008. Geology of the giant Sudbury polymetallic mining camp, Ontario, Canada. Economic Geology, 103, 1057-1077.

Amor, K., Hesselbo, S.P., Porcelli, D., Thackrey, S. \& Parnell, J. 2008. A Precambrian proximal ejecta blanket from Scotland. Geology, 36, 303-306.

Amor, K., Hesselbo, S.P., et al. 2019. The Mesoproterozoic Stac Fada proximal ejecta blanket, NW Scotland: constraints on crater location from field observations, anisotropy of magnetic susceptibility, petrography and geochemistry. Journal of the Geological Society, 176, 830-846, https://doi.org/10.1144/jgs2018-093.

Artemieva, N.A., Wünnemann, K., Krien, F., Reimold, W.U. \& Stöffler, D. 2013. Ries crater and suevite revisited - Observations and modeling Part II: Modeling. Meteoritics \& Planetary Science, 48, 515-589, https://doi.org/10.1111/maps.12085.

Barlow, N.G. 2005. A review of martian impact crater ejecta structrues and their implications for target properties. In: Kenkmann, T., Hörz, F. \& Deutsch, A. (eds) Large Meteorite Impacts III: Geological Society of America Special Paper 384. Boulder, Geological Society of America, 433-442.

Branney, M.J. \& Brown, R.J. 2011. Impactoclastic density current emplacement of terrestrial meteorite-impact ejecta and the formation of dust pellets and accretionary lapilli: Evidence from Stac Fada, Scotland. The Journal of Geology, 119, 275-292.

Butler, R.W.H. \& Alsop, I. 2019. A reassessment of the proposed 'Lairg Impact Structure' and its potential implications for the deep structure of northern Scotland: a discussion. 
543 Büttner, R., Dellino, P., La Volpe, L., Lorenz, V. \& Zimanowski, B. 2002. Thermohydraulic

544 explosions in phreatomagmatic eruptions as evidenced by the comparison between pyroclasts and products from Molten Fuel Coolant Interaction experiments. Journal of Geophysical Research: Solid Earth, 107, doi:10.1029/2001JB000511.

Chanou, A., Osinski, G.R. \& Grieve, R.A.F. 2014. A methodology for the semi-automatic digital image analysis of fragmental impactites. Meteoritics \& Planetary Science, 49, 621-635, https://doi.org/10.1111/maps.12267.

Christeson, G.L., Gulick, S.P.S., et al. 2018. Extraordinary rocks from the peak ring of the Chicxulub impact crater: P-wave velocity, density, and porosity measurements from IODP/ICDP Expedition 364. Earth and Planetary Science Letters, 495, 1-11, https://doi.org/https://doi.org/10.1016/j.epsl.2018.05.013.

Dence, M.R. 1971. Impact melts. Journal of Geophysical Research, 76, 5552-5565.

Drake, S.M., Beard, A.D., et al. 2017. Discovery of a meteoritic ejecta layer containing unmelted impactor fragments at the base of Paleocene lavas, Isle of Skye, Scotland. Geology, 46, 171-174, https://doi.org/10.1130/G39452.1.

Emmons, R.C. 1943. The Universal Stage (with Five Axes of Rotation), Geological Society of America Memoir 8. Boulder, Geological Society of America.

Engelhardt, W. v. \& Bertsch, W. 1969. Shock induced planar deformation structures in quartz from the Ries crater, Germany. Contributions to Mineralogy and Petrology, 20, 203234.

Engelhardt, W. v. 1990. Distribution, petrography and shock metamorphism of the ejecta of the Ries crater in Germany - a review. Tectonophysics, 171, 259-273.

Engelhardt, W. v. 1997. Suevite breccia of the Ries impact crater, Germany: Petrography, 

chemistry and shock metamorphism of crystalline rock clasts. Meteoritics \& Planetary Science, 32, 545-554.

Engelhardt, W. v \& Graup, G. 1984. Suevite of the Ries crater, Germany: Source rocks and implications for cratering mechanics. Geologische Rundschau, 73, 447-481.

Ferrière, L. \& Osinski, G.R. 2012. Shock Metamorphism. In: Osinski, G. R. \& Pierazzo, E. (eds) Impact Cratering: Processes and Products. Chichester, Wiley-Blackwell, 106-124.

Ferrière, L., Koeberl, C., Ivanov, B.A. \& Reimold, W.U. 2008. Shock Metamorphism of Bosumtwi Impact Crater Rocks, Shock Attenuation, and Uplift Formation. Science, 322, 1678-1681, https://doi.org/10.1126/science.1166283.

Ferrière, L., Morrow, J.R., Amgaa, T. \& Koeberl, C. 2009a. Systematic study of universalstage measurements of planar deformation features in shocked quartz: Implications for statistical significance and representation of results. Meteoritics \& Planetary Science, 44, 925-940.

Ferrière, L., Koeberl, C., Reimold, W.U., Hecht, L. \& Bartosova, K. 2009b. The origin of “toasted" quartz in impactites revisited. Lunar and Planetary Science Conference, $\mathbf{4 0 ,}$ 1751 pdf.

French, B.M. 1967. Sudbury Structure, Ontario: Some petrographic evidence for origin by meteorite impact. Science, 156, 1094-1098, https://doi.org/10.1126/science.156.3778.1094.

French, B.M. \& Koeberl, C. 2010. The convincing identification of terrestrial meteorite impact structures: What works, what doesn't, and why. Earth-Science Reviews, 98, 123 170.

Gracie, A.J. \& Stewart, A.D. 1967. Torridonian sediments at Enard Bay, Ross-shire. Scottish Journal of Geology, 3, 181 LP - 194, https://doi.org/10.1144/sjg03020181. 
Grieve, R.A.F. 2017. Logan Medallist 4. Large-Scale Impact and Earth History. Geoscience Canada; Volume 44, Number 1 (2017)DO - 10.12789/geocanj.2017.44.113.

Grieve, R.A.F., Ames, D.E., Morgan, J. V \& Artemieva, N. 2010. The evolution of the Onaping Formation at the Sudbury impact structure. Meteoritics \& Planetary Science, 45, 759-782, https://doi.org/10.1111/j.1945-5100.2010.01057.x.

Hill, P.J.A., Osinski, G.R. \& Banerjee, N.R. 2020. Through the impact glass: Insight into the evolution of melt at the Mistastin Lake impact structure. Meteoritics \& Planetary Science, doi:10.1111/maps.13457, https://doi.org/10.1111/maps.13457.

Hörz, F. 1968. Statistical measurements of deformation structures and refractive indices in experimentally shock loaded quartz. In: French, B. M. \& Short, N. M. (eds) Shock Metamorphism of Natural Materials. Baltimore, Mono Book Corporation, 243-253.

Hörz, F. 1982. Ejecta of the Ries Crater, Germany. In: Silver, L. T. \& Schultz, P. H. (eds) Geological Implications of Impacts of Large Asteroids and Comets on the Earth, Geological Society of America Special Paper 190. Boulder, Colorado, USA, Geological Society of America, 39-55.

Hörz, F., Ostertag, R. \& Rainey, D.A. 1983. Bunte breccia of the Ries: Continuous deposits of large impact craters. Reviews of Geophysics and Space Physics, 21, 1667-1725.

Huber, M.S., Ferrière, L., Losiak, A. \& Koeberl, C. 2011. ANIE: A mathematical algorithm for automated indexing of planar deformation features in quartz grains. Meteoritics \& Planetary Science, 46, 1418-1424, https://doi.org/10.1111/j.1945-5100.2011.01234.x.

Huffman, A.R. \& Reimold, W.U. 1996. Experimental constraints on shock-induced microstructures in naturally deformed silicates. Tectonophysics, 256, 165-217, https://doi.org/https://doi.org/10.1016/0040-1951(95)00162-X.

Johnson, B.C. \& Melosh, H.J. 2014. Formation of melt droplets, melt fragments, and 

accretionary impact lapilli during a hypervelocity impact. Icarus, 228, 347-363, https://doi.org/10.1016/j.icarus.2013.10.022.

616 Kenny, G.G., O’Sullivan, G.J., Alexander, S., Simms, M.J., Chew, D.M. \& Kamber, B.S. 2019. On the track of a Scottish impact structure: a detrital zircon and apatite provenance

Lawson, D.E. 1973. Torridonian volcanic sediments. Scottish Journal of Geology, 8, 345 LP -

Mader, M.M. \& Osinski, G.R. 2018. Impactites of the Mistastin Lake impact structure: Insights into impact ejecta emplacement. Meteoritics \& Planetary Science, 53, 24922518.

Melosh, H.J. 1989. Impact Cratering: A Geologic Process. New York, Oxford University 626 Press.

Muir, T.L. \& Peredery, W.V. 1984. The Onaping Formation. In: Pye, E. G., Naldrett, A. J. \&

Müller, W.F. \& Défourneaux, M. 1968. Deformationsstrukturen im Quarz als Indikator für Stosswellen: Eine experimentelle Untersuchung an Quartz-Einkristallen. Geophysik, 34,

Oberbeck, V.R. 1975. The role of ballistic erosion and sedimentation in lunar stratigraphy. Reviews of Geophysics and Space Physics, 13, 337-362.

Oberbeck, V.R. 2009. Layered ejecta craters and the early water/ice aquifer on Mars. 5100.2009.tb00716.x. 
638 Osinski, G.R. 2006. Effect of volatiles and target lithology on the generation and emplacement of impact crater fill and ejecta deposits on Mars. Meteoritics \& Planetary Science, 41, 1571-1586.

Osinski, G.R. \& Grieve, R.A.F. 2019. Impact Earth: A new resource for outreach, teaching, and research. Elements, 15, 70-71.

Osinski, G.R. \& Pierazzo, E. 2012. Impact Cratering: Processes and Products. WileyBlackwell.

Osinski, G.R., Grieve, R.A.F. \& Spray, J.G. 2004. The nature of the groundmass of surficial suevites from the Ries impact structure, Germany, and constraints on its origin.

Osinski, G.R., Tornabene, L.L. \& Grieve, R.A.F. 2011. Impact ejecta emplacement on the terrestrial planets. Earth and Planetary Science Letters, 310, 167-181.

Osinski, G.R., Grieve, R.A.F. \& Tornabene, L.L. 2012. Excavation and impact ejecta emplacement. In: Osinski, G. R. \& Pierazzo, E. (eds) Impact Cratering: Processes and

Osinski, G.R., Grieve, R.A.F., Chanou, A. \& Sapers, H.M. 2016. The “suevite” conundrum, Part 1: The Ries suevite and Sudbury Onaping Formation compared. Meteoritics and

Osinski, G.R., Grieve, R.A.F., Bleacher, J.M., Neish, C.D., Pilles, E.A. \& Tornabene, L.L. 2018. Igneous rocks formed by hypervelocity impact. Journal of Volcanological and Geothermal Research, 353, 25-54.

Osinski, G.R., Grieve, R.A.F., et al. 2020. Explosive interaction of impact melt and seawater following the Chicxulub impact event. Geology, 48, 108-112, https://doi.org/10.1130/G46783.1. 
662 Parnell, J., Mark, D., Fallick, A.E., Boyce, A. \& Thackrey, S. 2011. The age of the

663

664

665

666

667

668

669

670

671

672

673

674

675

676

677

678

679

680

681

682

683

684

685 Mesoproterozoic Stoer Group sedimentary and impact deposits, NW Scotland. Journal of the Geological Society, 168, 349-358, https://doi.org/10.1144/0016-76492010-099.

Reddy, S.M., Johnson, T.E., Fischer, S., Rickard, W.D.A. \& Taylor, R.J.M. 2015. Precambrian reidite discovered in shocked zircon from the Stac Fada impactite, Scotland. Geology, 43, 899-902, https://doi.org/10.1130/G37066.1.

Sanders, I.S. \& Johnston, J.D. 1989. The Torridonian Stac Fada Member: an extrusion of fluidised peperite? Transactions of the Royal Society of Edinburgh: Earth Sciences, 80, 1-4, https://doi.org/DOI: 10.1017/S0263593300012220.

Self, S. \& Sparks, R.S.J. 1978. Characteristics of widespread pyroclastic deposits formed by the interaction of silicic magma and water. Bulletin Volcanologique, 41, 196-212, https://doi.org/10.1007/BF02597223.

Shoemaker, E.M. 1963. Impact mechanics at Meteor Crater, Arizona. In: Middlehurst, B. M. \& Kuiper, G. P. (eds) The Moon, Meteorites and Comets. Illinois, University of Chicago Press, 301-336.

Siegert, S., Branney, M.J. \& Hecht, L. 2017. Density current origin of a melt-bearing impact ejecta blanket (Ries suevite, Germany). Geology, 45, 855-858.

Simms, M.J. 2015. The Stac Fada impact ejecta deposit and the Lairg Gravity Low: evidence for a buried Precambrian impact crater in Scotland? Proceedings of the Geologists' Association, 126, 742-761, https://doi.org/https://doi.org/10.1016/j.pgeola.2015.08.010.

Simms, M.J. 2019. Reply to Discussion on 'A reassessment of the proposed "Lairg Impact Structure" and its potential implications for the deep structure of northern Scotland'. Journal of the Geological Society, jgs2019-186, https://doi.org/10.1144/jgs2019-186.

Simms, M.J. \& Ernstson, K. 2019. A reassessment of the proposed 'Lairg Impact Structure' 

and its potential implications for the deep structure of northern Scotland. Journal of the Geological Society, https://doi.org/10.1144/jgs2017-161.

Stewart, A.D. 2002. The Later Proterozoic Torridonian Rocks of Scotland: Their Sedimentology, Geochemistry and Origin. London, The Geological Society of London.

Stöffler, D. 1972. Deformation and transformation of rock-forming minerals by natural and experimental shock processes: I. Behavior of minerals under shock compression. Fortschritte der Mineralogie, 49, 50-113.

Stöffler, D. 1984. Glasses formed by hypervelocity impact. Journal of Non-Crystalline Solids, 67, 465-502.

Stöffler, D. \& Grieve, R.A.F. 2007. Impactites. In: Fettes, D. \& Desmons, J. (eds) Metamorphic Rocks. Cambridge, Cambridge University Press, 82-92.

Stöffler, D. \& Langenhorst, F. 1994. Shock metamorphism of quartz in nature and experiment: 1. Basic observation and theory. Meteoritics, 29, 155-181.

Stöffler, D., Artemieva, N.A., Wünnemann, K., Reimold, W.U., Jacob, J., Hansen, B.K. \& Summerson, I.A.T. 2013. Ries crater and suevite revisited-Observations and modeling Part I: Observations. Meteoritics \& Planetary Science, 48, 515-589.

Stüeken, E.E., Bellefroid, E.J., Prave, A., Asael, D., Planavsky, N.J. \& Lyons, T.W. 2017. Not so non-marine? Revisiting the Stoer Group and the Mesoproterozoic biosphere. Geochemical Perspectives Letters, 3, 221-229, https://doi.org/http://dx.doi.org/10.7185/geochemlet.1725.

Sturm, S., Wulf, G., Jung, D. \& Kenkmann, T. 2013. The Ries impact, a double-layer rampart crater on Earth. Geology, 41, 531-534, https://doi.org/10.1130/G33934.1.

Walkden, G., Parker, J. \& Kelley, S. 2002. A Late Triassic Impact Ejecta Layer in Southwestern Britain. Science, 298, 2185-2188. 
710 Whitehead, J., Spray, J.G. \& Grieve, R.A.F. 2002. Origin of 'toasted' quartz in terrestrial 711 impact structures. Geology, 30, 431-434.

712 Wohletz, K.H. 1983. Mechanisms of hydrovolcanic pyroclast formation: Grain-size, scanning 713 electron microscopy, and experimental studies. Journal of Volcanology and Geothermal 714 Research, 17, 31-63, https://doi.org/http://dx.doi.org/10.1016/0377-0273(83)90061-6.

715 Wohletz, K.H., Zimanowski, B. \& Buttner, R. 2013. Magma-water interactions. In: Fagents, 716 S. A., Gregg, T. K. P. \& Lopes, R. M. C. (eds) Modeling Volcanic Processes: The 717 Physics and Mathematics of Volcanism. Cambridge University Press, 230-257.

718 Young, G.M. 2002. Stratigraphy and geochemistry of volcanic mass flows in the Stac Fada 719 Member of the Stoer Group, Torridonian, NW Scotland. Transactions: Earth Sciences, $720 \quad 93,1-16$. 
Table 1. Basic characteristics of the Stac Fada Member, compared with Ries and Mistastin "suevite", the Sudbury Onaping Formation, and Chicxulub impact melt-bearing breccias from

728 the International Ocean Discovery Program / International Continental Scientific Drilling

729 Program Expedition 364, site M0077A $\left(21.45^{\circ} \mathrm{N}, 89.95^{\circ} \mathrm{W}\right)$. Table expanded from Osinski et

730 al. (2020).

\begin{tabular}{|c|c|c|c|c|c|}
\hline & $\begin{array}{l}\text { Ries (Engelhardt \& } \\
\text { Graup 1984; } \\
\text { Engelhardt 1997; } \\
\text { Osinski et al. } \\
\text { 2004) }\end{array}$ & $\begin{array}{l}\text { Mistastin } \\
\text { (Mader \& } \\
\text { Osinski 2018) }\end{array}$ & $\begin{array}{l}\text { Chicxulub } \\
\text { (Osinski et al. } \\
\text { 2020) }\end{array}$ & $\begin{array}{l}\text { Sudbury (Muir } \\
\text { \& Peredery } \\
\text { 1984; Ames et } \\
\text { al. 2002, 2008; } \\
\text { Grieve et al. } \\
\text { 2010) }\end{array}$ & $\begin{array}{l}\text { Stac Fada (this } \\
\text { study and as } \\
\text { noted) }\end{array}$ \\
\hline Stratigraphy & $\begin{array}{l}\text { No internal } \\
\text { stratigraphy }\end{array}$ & $\begin{array}{l}\text { No internal } \\
\text { stratigraphy }\end{array}$ & $\begin{array}{l}\text { Internal } \\
\text { lithologies; } \\
\text { layered on } \mathrm{mm} \\
\text { to } \mathrm{dm} \text {-scale }\end{array}$ & $\begin{array}{l}\text { Internal } \\
\text { lithologies; } \\
\text { layered }\end{array}$ & $\begin{array}{l}\text { Internal } \\
\text { lithologies; } \\
\text { layered on mm } \\
\text { to dm-scale } \\
\text { (cf., Gracie and } \\
\text { Stewart 1967; } \\
\text { Simms 2015). }\end{array}$ \\
\hline $\begin{array}{l}\text { Relationship to } \\
\text { topography }\end{array}$ & $\begin{array}{l}\text { Deposits infill } \\
\text { topography }\end{array}$ & $\begin{array}{l}\text { Deposits infill } \\
\text { topography }\end{array}$ & $\begin{array}{l}\text { Deposits drape } \\
\text { topography } \\
\text { (Christeson et } \\
\text { al. 2018) }\end{array}$ & $\begin{array}{l}\text { Deposits drape } \\
\text { topography }\end{array}$ & $\begin{array}{l}\text { Deposits infill } \\
\text { and drape } \\
\text { topography } \\
\text { (Stewart 2002; } \\
\text { Simms 2015). }\end{array}$ \\
\hline Sorting & $\begin{array}{l}\text { Poorly to very } \\
\text { poorly sorted }\end{array}$ & $\begin{array}{l}\text { Poorly to very } \\
\text { poorly sorted }\end{array}$ & $\begin{array}{l}\text { Well to very } \\
\text { well sorted }\end{array}$ & $\begin{array}{l}\text { Well to very } \\
\text { well sorted }\end{array}$ & $\begin{array}{l}\text { Moderately to } \\
\text { very well sorted }\end{array}$ \\
\hline Graded? & No & No & Yes & Yes & Yes \\
\hline \multicolumn{6}{|l|}{ Vitric clasts: } \\
\hline Vol. \% & $\begin{array}{l}\text { Average } 16 \text { vol\% } \\
\text { (although finer } \\
\text { fraction of the } \\
\text { groundmass also } \\
\text { has glass particles) }\end{array}$ & $\begin{array}{l}\text { Average } 15-20 \\
\text { vol } \%\end{array}$ & $>50 \mathrm{vol} \%$ & $\begin{array}{l}>60 \text { vol } \% \text {; up to } \\
80 \text { vol } \% \text { in the } \\
\text { Sandcherry } \\
\text { Formation }\end{array}$ & $\begin{array}{l}\text { Typically }>55 \\
\text { vol } \%\end{array}$ \\
\hline Size & $\begin{array}{l}\text { Typically } 1-10 \mathrm{~cm} \text {, } \\
\text { but up to } 1 \mathrm{~m} \text { long } \\
\text { in places }\end{array}$ & $\begin{array}{l}\text { Typically } 1-10 \\
\mathrm{~cm} \text {, but up to } \\
0.8 \mathrm{~m} \text { long in } \\
\text { places }\end{array}$ & $\begin{array}{l}\text { Typically } 100 \mathrm{~s} \\
\mu \mathrm{m} \text { to } \sim 5 \mathrm{~mm} ; \\
\text { rarely }>1 \mathrm{~cm}\end{array}$ & $\begin{array}{l}\text { Typically } 100 \mathrm{~s} \\
\mu \mathrm{m} \text { to } 1-5 \mathrm{~mm} \\
\text { rarely }>1 \mathrm{~cm}\end{array}$ & $\begin{array}{l}\text { Typically } 100 \mathrm{~s} \\
\mu \mathrm{m} \text { to } 1-5 \mathrm{~mm} \text {; } \\
\text { rarely }>1 \mathrm{~cm} \\
\text { (cf., Amor et al. } \\
\text { 2008; Simms } \\
2015 \text { ). }\end{array}$ \\
\hline Shape & Irregular & Irregular & Regular, equant & Regular, equant & Regular, equant \\
\hline Alignment? & Yes & Yes & No & No & No to Rare \\
\hline $\begin{array}{l}\text { Mineral/ lithic } \\
\text { fragments in } \\
\text { clasts? }\end{array}$ & Abundant & Abundant & Rare & Rare & Rare \\
\hline Vesicles? & Abundant & Abundant & Rare & Rare & Variable \\
\hline Schlieren? & Abundant & Abundant & Rare & None/rare & None/rare \\
\hline $\begin{array}{l}\text { Quench } \\
\text { crystallites? }\end{array}$ & Abundant & Abundant & None/rare & None & None \\
\hline $\begin{array}{l}\text { Impact melt } \\
\text { rock clasts? }\end{array}$ & None & None & Yes & Yes & None \\
\hline $\begin{array}{l}\text { Deposition } \\
\text { temperature }\end{array}$ & $\operatorname{High}\left(>900^{\circ} \mathrm{C}\right)$ & High $\left(>900^{\circ} \mathrm{C}\right)$ & Low $\left(<580{ }^{\circ} \mathrm{C}\right)$ & Low & $\begin{array}{l}\text { Low }\left(\sim 200^{\circ} \mathrm{C}\right) \\
\text { (Parnell et al. } \\
\text { 2011) }\end{array}$ \\
\hline $\begin{array}{l}\text { Shock level of } \\
\text { lithic clasts }\end{array}$ & $\begin{array}{l}>90 \% \text { shocked to } \\
>10 \mathrm{GPa}\end{array}$ & $\begin{array}{l}>75 \% \text { shocked } \\
\text { to }>10 \mathrm{GPa}\end{array}$ & $<<5 \%$ shocked & $<<5 \%$ shocked & $<<5 \%$ shocked \\
\hline
\end{tabular}


Table 2. Characteristics of quartz grains and main petrographic observations as determined by optical microscopy on 26 thin sections of the different types of breccia samples from the Bay of Stoer.

\begin{tabular}{|c|c|c|c|c|c|c|c|c|}
\hline & \multirow[b]{2}{*}{ UTM Coordinates } & \multirow{2}{*}{ PFs } & \multicolumn{4}{|c|}{ PDFs } & \multirow{2}{*}{$\begin{array}{l}\text { Decorated } \\
\text { PFs/PDFs }\end{array}$} & \multirow{2}{*}{ Notes } \\
\hline & & & $1 \mathrm{set}$ & 2 sets & 3 sets & 4 sets & & \\
\hline \multicolumn{9}{|c|}{ Impact melt-bearing breccia } \\
\hline SF08 002A & NC 0332728532 & 1 & 3 & & & & 4 & Kink bands in muscovite \\
\hline SF08 002B & NC 0332728532 & 1 & 1 & 1 & 1 & & & - \\
\hline SF08 003A & NC 0333028545 & 1 & 3 & 1 & 1 & & 3 & Kink bands in muscovite \\
\hline SF08 003B & NC 0333028545 & 1 & 3 & 1 & & & 1 & One quartz grain with two PDF sets occurs within a vitric melt clast. \\
\hline SF08 004A & NC 0332328533 & & 1 & 2 & & & 2 & Kink bands in muscovite and rarely in feldspar grains \\
\hline SF08 004B & NC 0332328533 & 1 & 3 & 2 & & & 1 & - \\
\hline SF08 005A & NC 0331728548 & 1 & 1 & 2 & 2 & 2 & 2 & A few toasted quartz grains occur \\
\hline SF08 005B & NC 0331728548 & 1 & 4 & 2 & & & 1 & $\begin{array}{l}\text { Occurrence of a very vitric clast containing abundant undigested mineral clasts (mainly quartz } \\
\text { but also a few feldspar grains). }\end{array}$ \\
\hline SF08 005C & NC 0331728548 & & 2 & & 1 & & & Presence of shard-like vitric clasts \\
\hline SF08 010A* & NC 0310714582 & & & & & & & Occurrence of vitric clasts recrystallized/altered to chlorite and zeolite \\
\hline SF08 010B & NC 0310714582 & & 3 & 1 & 1 & & 2 & $\begin{array}{l}\text { One quartz grain with one set of highly decorated PDF occurs within a vitric clasts. The thin } \\
\text { section displays a large amount of vesicular vitric clasts }\end{array}$ \\
\hline SF08 011 & NC 0310714582 & & 2 & 1 & & & 1 & Several highly fractured feldspar grains occur \\
\hline SF08 012A & NC 0313014598 & & 1 & & & & 1 & - \\
\hline SF08 012B* & NC 0313014598 & & & & & & & $\begin{array}{l}\text { Several toasted quartz grains occur. Kink bands in muscovite. Many altered vitric clasts with } \\
\text { numerous undigested angular quartz grains }\end{array}$ \\
\hline \multicolumn{9}{|c|}{ Impact melt-bearing breccia with lapilli } \\
\hline SF08 009A & NC 0308114593 & 1 & 1 & & & & & Presence of lapilli; the two shocked quartz grains occur within a lapilli \\
\hline SF08 009B & NC 0308114593 & & 2 & & & & 2 & Presence of lapilli \\
\hline \multicolumn{9}{|c|}{ Other type of breccia } \\
\hline SF08 001A & NC 0332628530 & 2 & 1 & & & & & Kink bands in micas. No melt particles occur. \\
\hline SF08 001B & NC 0332628530 & 4 & 1 & & & & 1 & Kink bands in micas. No melt particles occur. \\
\hline
\end{tabular}

$\left(^{*}\right)$ Samples in which shocked quartz were not detected during our investigations. 
Table 3. PDF set abundances and indexed PDF crystallographic orientations in quartz grains from 16 thin sections of breccia samples from the Bay of Stoer, as determined using the universal-stage.

\begin{tabular}{lr}
\hline No. of investigated grains & 48 \\
No. of measured sets & 78 \\
No. of PDF sets/grain (N) & 1.6 \\
PDF sets; \% relative to total no. of quartz grains examined & 60 \\
1 set & 21 \\
2 sets & 15 \\
3 sets & 4 \\
4 sets & 100 \\
Total &
\end{tabular}

Indexed PDF crystallographic orientations; absolute frequency $(\%)^{\mathrm{a}}$ PDF crystallographic orientations

\begin{tabular}{lr}
$\mathrm{c}(0001)$ & 3.8 \\
$\{10 \overline{1} 4\}$ & 14.1 \\
$\{10 \overline{1} 4\} / /\{10 \overline{1} 3\}^{\mathrm{b}}$ & 17 \\
$\omega\{10 \overline{1} 3\}^{\mathrm{c}}$ & 46 \\
$\pi\{10 \overline{1} 2\}$ & 14 \\
$\mathrm{r}, \mathrm{z}\{10 \overline{1} 1\}$ & n.d. \\
$\mathrm{m}\{10 \overline{1} 0\}$ & n.d. \\
$\xi\{11 \overline{2} 2\}$ & n.d. \\
$\mathrm{s}\{11 \overline{2} 1\}$ & n.d. \\
$\rho\{21 \overline{3} 1\}$ & 2.6 \\
$\mathrm{X}\{51 \overline{6} 1\}$ & n.d. \\
$\mathrm{a}\{11 \overline{2} 0\}$ & n.d. \\
$\{22 \overline{4} 1\}$ & 1.3 \\
$\{31 \overline{4} 1\}$ & n.d. \\
$\mathrm{t}\{40 \overline{4} 1\}$ & n.d. \\
$\mathrm{k}\{51 \overline{6} 0\}$ & n.d. \\
Unindexed & 1.3 \\
Total & n \\
\hline
\end{tabular}

${ }^{a}$ Method described in Ferrière et al. (2009a); indexing done using the Automated Numerical Index Executor program (using the average value of measurements and a $5^{\circ}$ error; see Huber et al. 2011).

${ }^{b}$ PDF planes which plot in the overlapping zone between $\{10 \overline{1} 4\}$ and $\{10 \overline{1} 3\}$ crystallographic orientations.

c $\{10 \overline{1} 3\}$ PDF orientations uniquely indexed.

n.d. = none detected. 


\section{Figure captions}

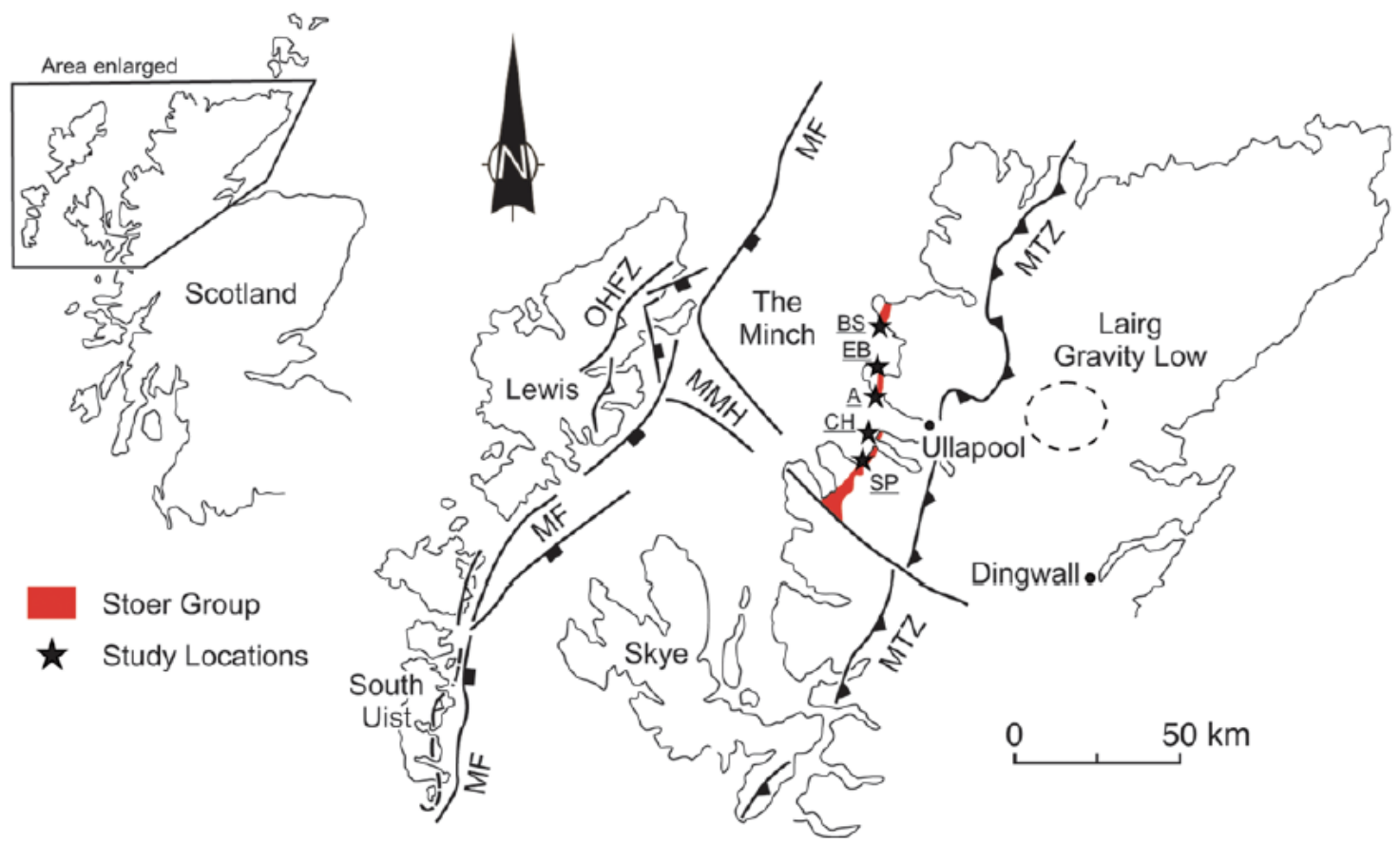

Fig. 1. Simplified map of NW Scotland highlighting the location of the Stoer Group in red.

The 5 study locations, from north to south, are Bay of Stoer $(\underline{B S})$, Enard Bay ( $\underline{\mathrm{EB}})$,

Achiltibuie ( $\underline{\mathrm{A}})$, Cailleach Head $(\mathrm{CH})$, and Stattic Point (SP). Other abbreviations: $\mathrm{MF}=$

Minch Fault; MMH = Mid-Minch High; MTZ = Moine Thrust Zone; OHFZ = Outer Hebrides

Fault Zone. 

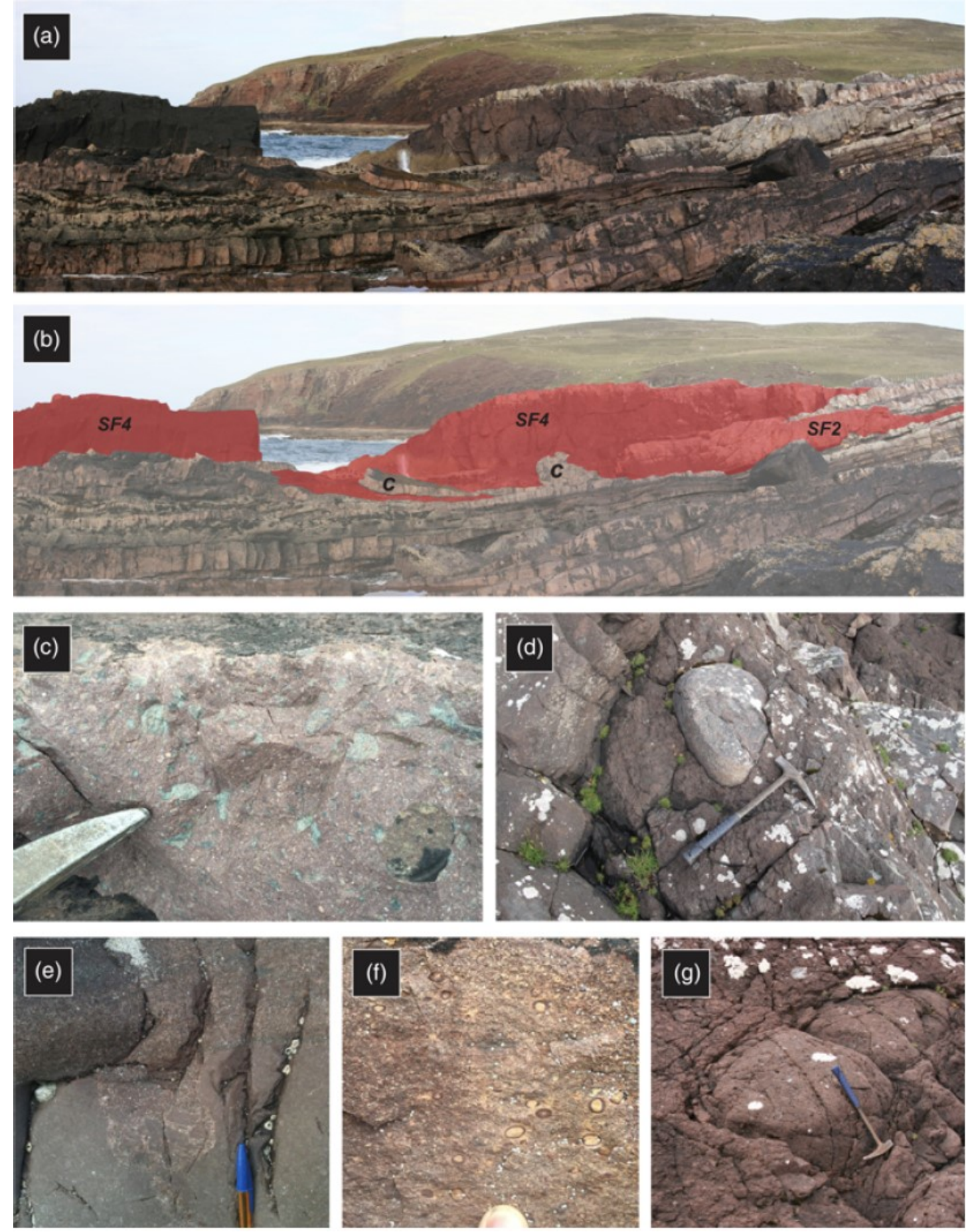

Fig. 2. Field photographs of the Stac Fada Member. (a) Bay of Stoer locality. (b) Same image as (a) with the Stac Fada Member highlighted in a red overlay. "SF2" and "SF4" correspond to the units of Young (2002) (see text for further details). "c" are two large sandstone clasts. (c) Classic example of the Stac Fada Member with green vitric clasts. Tip of rock hammer for scale. Bay of Stoer locality. (d) Rounded gneiss clast, centre above $35 \mathrm{~cm}$-long rock hammer. Bay of Stoer locality. (e) The upper contact of the Stac Fada Member with overlying basal sandstones preserves evidence for erosion and reworking. (f) Accretionary lapilli at the Enard 
Bay locality. (g) Rock hammer resting on Stac Fada Member. The more rubbly outcrop wrapping around the "intact" Stac Fada Member is interpreted to be later channel fill deposits.
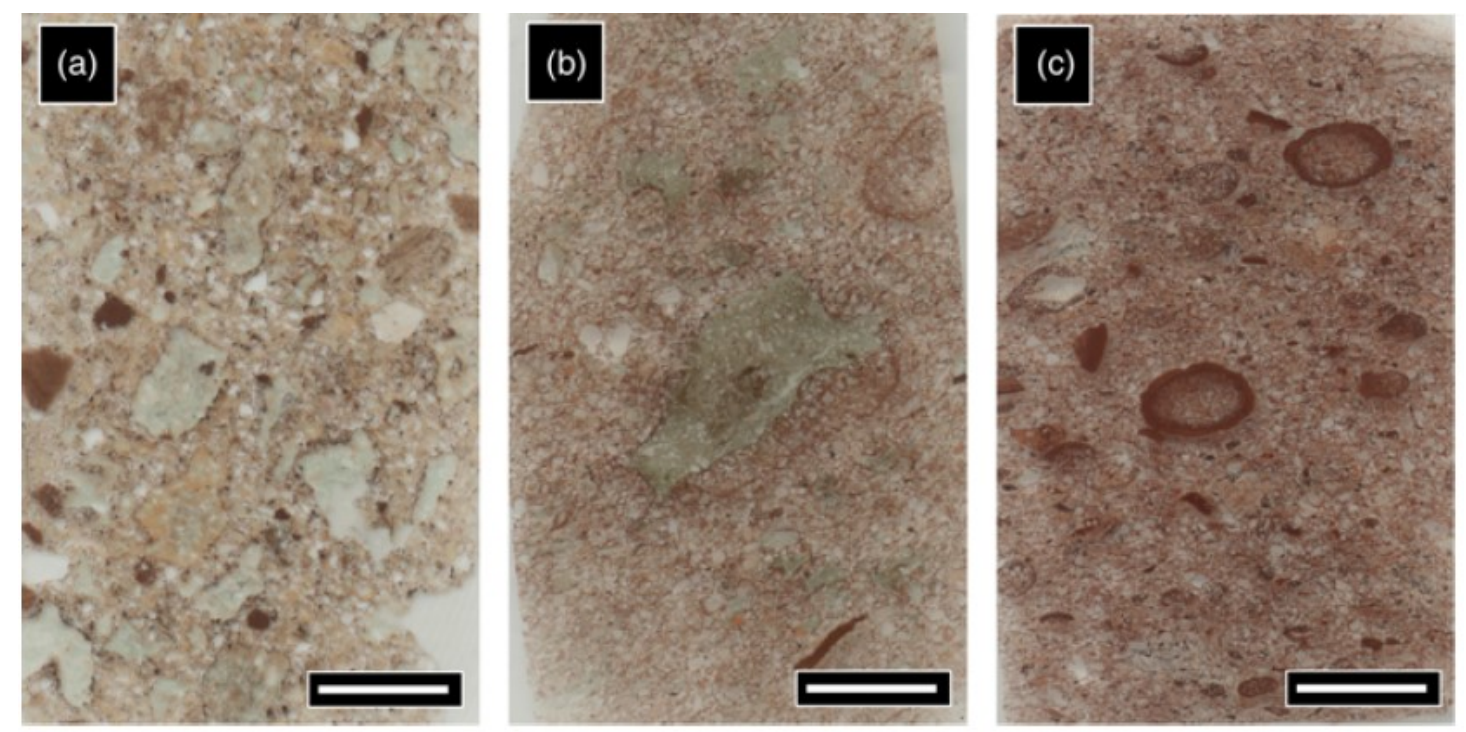

Fig. 3. Scanned polished thin sections of the Stac Fada Member melt-bearing breccias. All scale bars are $0.5 \mathrm{~cm}$ and all samples are from the Bay of Stoer locality.
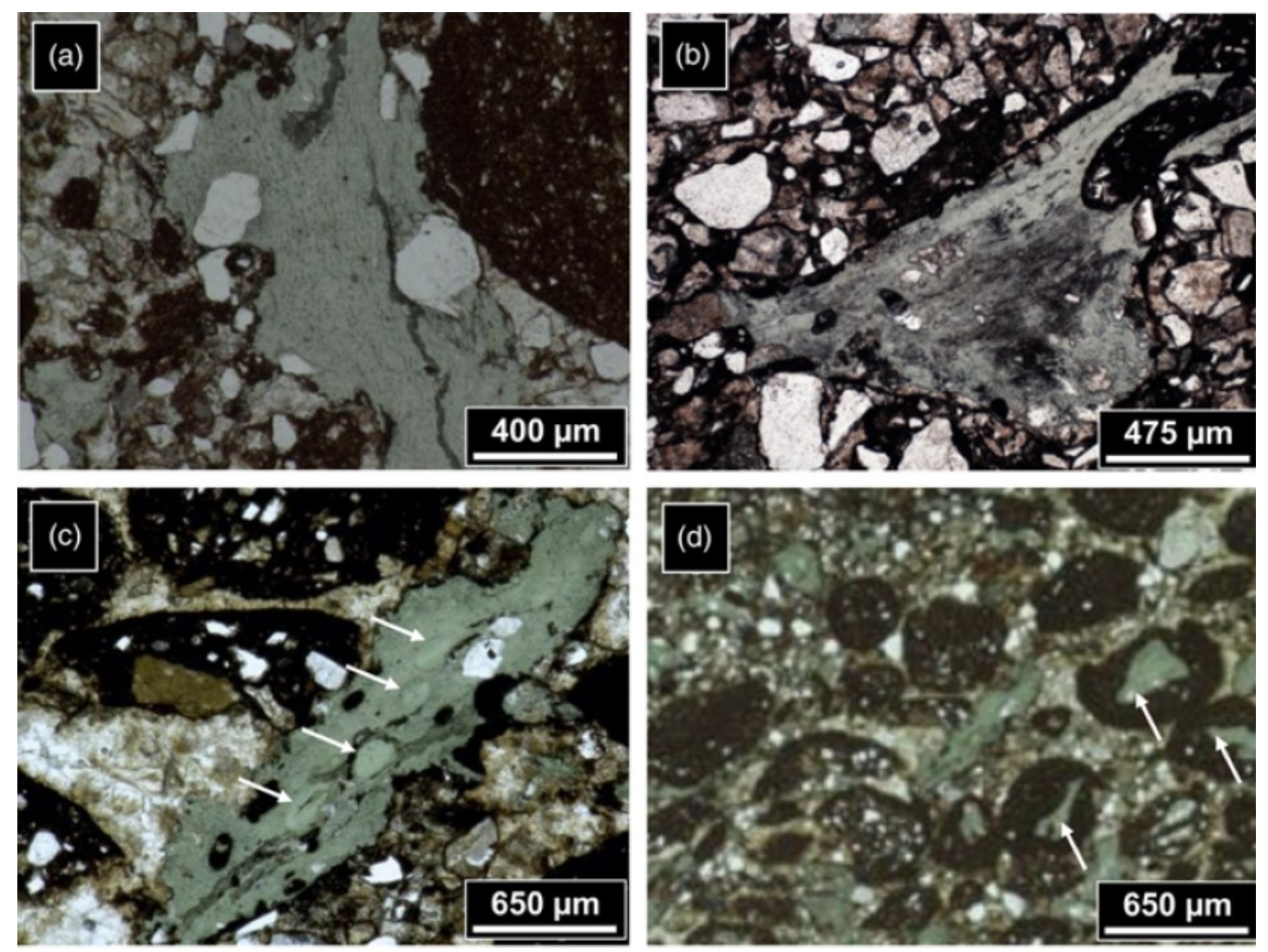

Fig. 4. Plane-polarized light photomicrographs of the Stac Fada Member melt-bearing breccias. (a) Shard-like, devitrified and altered melt fragment from Bay of Stoer. Note the 
presence of quartz mineral clasts (b) Devitrified and altered melt fragment from Bay of Stoer. Note the elongated shape of the large vesicle. (c) Devitrified and altered melt fragment with vesicles infilled with the same phase that altered the glass (white arrows). Bay of Stoer locality. (d) Accretionary lapilli-rich sample from Enard Bay. Note the presence of whole and broken lapilli. Some lapilli have glass fragments in their cores (white arrows).

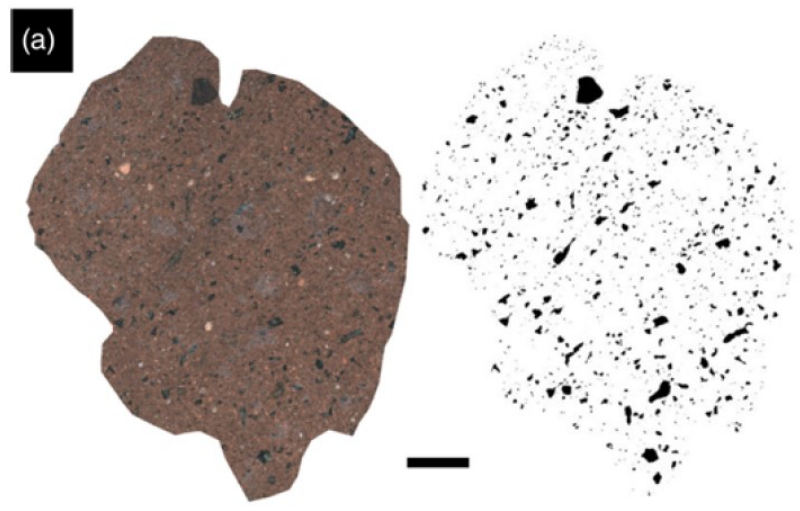

\section{(b)}

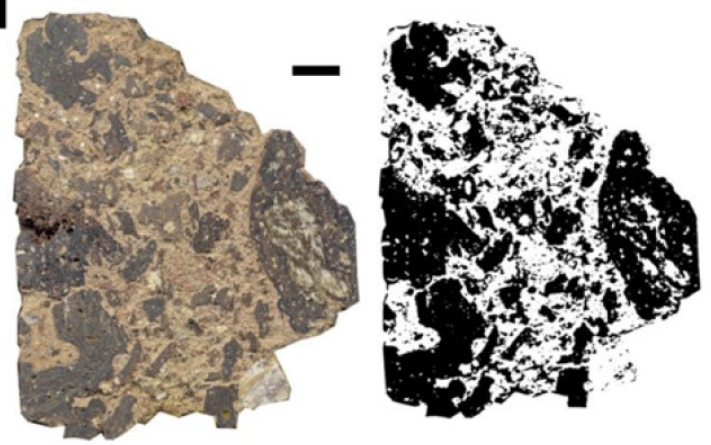

(c)

(d)
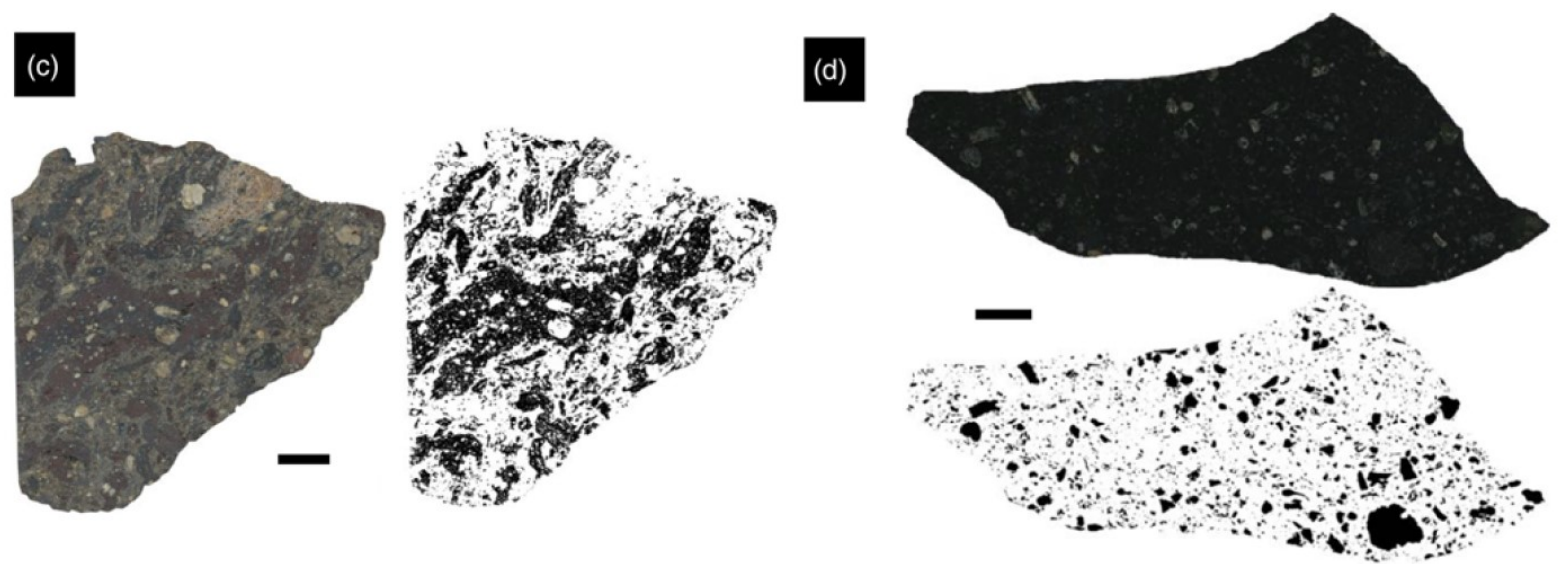

Fig. 5. Scanned hand specimen images and corresponding black and white image analysis products highlighting impact glass from the Stac Fada Member (a), Ries impact structure (Germany) (b), Mistastin Lake impact structure (Canada) (c), and the Onaping Formation of the Sudbury impact structure (Canada) (d). All scale bars are $1 \mathrm{~cm}$. 

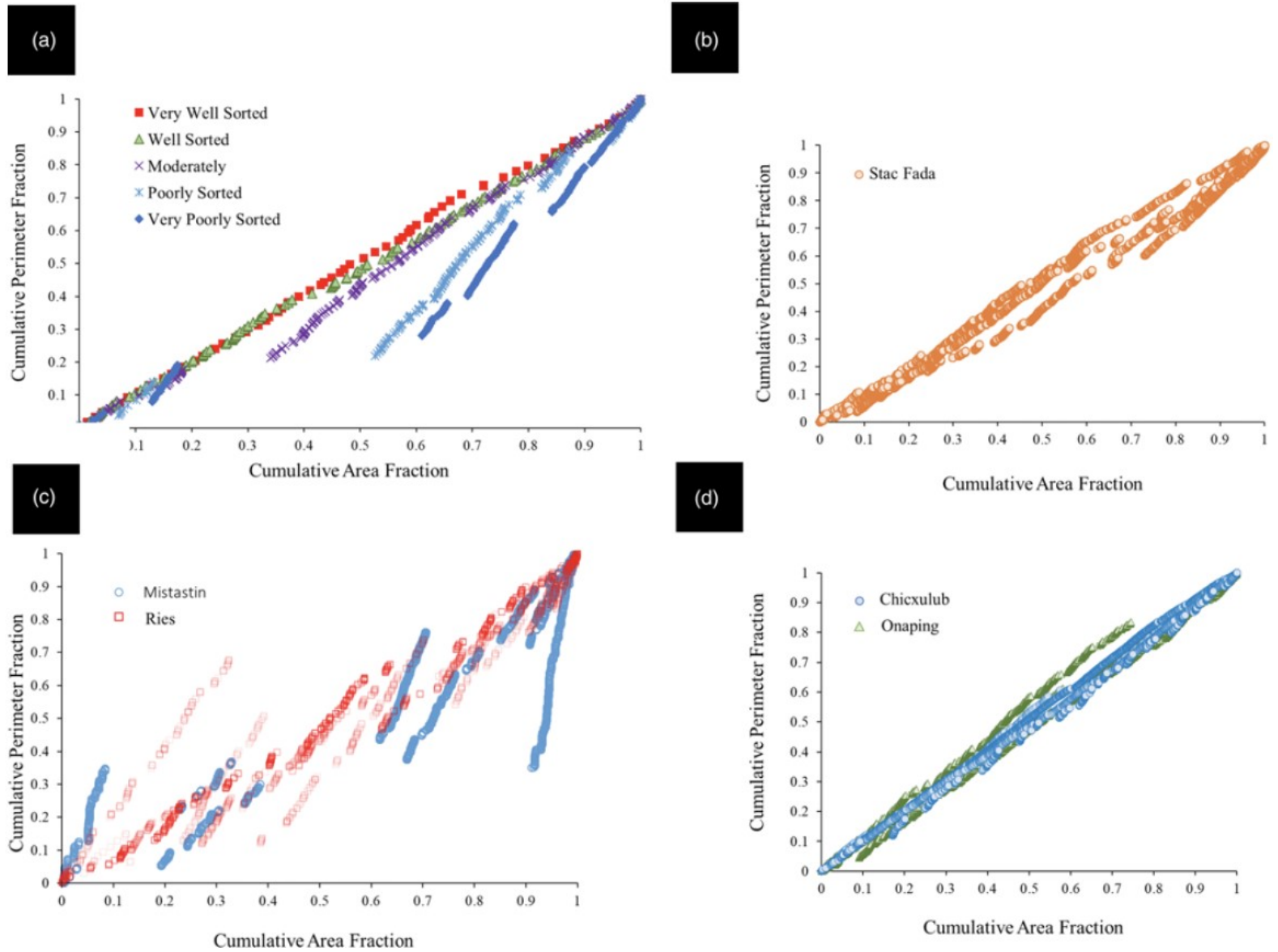

Fig. 6. Cumulative area and perimeter fraction plots to show the degree of sorting in Stac Fada Member and other impact melt-bearing breccia deposits. Here the cumulative area fraction is a running total of the area for particles of interest over the total area for all particles of interest. Likewise, the cumulative perimeter fraction is a running total of the perimeter for particles of interest over the total perimeter for all particles of interest. (a) Using the methods of Chanou et al. (2014), the results for a typical sorting scale clearly differentiate each sorting. The slope indicates the rate of fraction increase which is greater for poorly sorted samples. The cut-offs and jumps in the fractions are due to the occurrence of larger and more complex particles causing a shift in the cumulative values. The results for a typical sorting scale clearly differentiate each sorting level. Very well-sorted samples have a slope of $\sim 1$ and show a continuous linear distribution. Less sorted samples have progressively steeper and more discontinuous distributions. (b) Results for the Stac Fada Member demonstrate the high degree of sorting. (c) Traditional "suevite" from the Ries and Mistastin Lake impact structures (see Figs. 5b and c) are clearly more poorly sorted than the Stac Fada Member. (d) The Onaping Formation (see Fig. 5d) from the Sudbury impact structure and impact melt-bearing breccias from the Chicxulub impact structure (from IODP/ICDP Expedition 364, site M0077A) are well sorted, like the Stac Fada Member. 

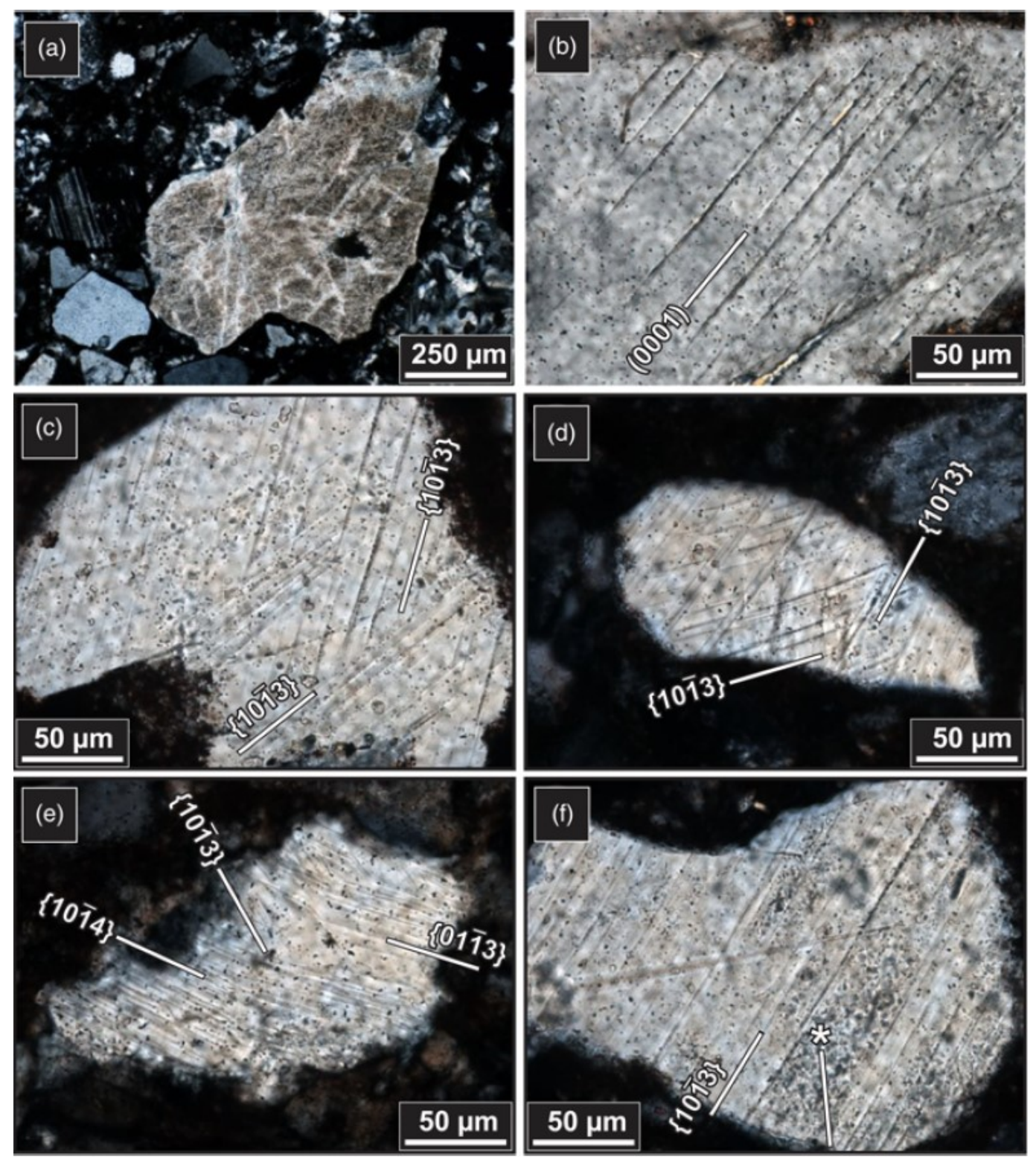

Fig. 7. Thin section photomicrographs (in cross-polarized light) of shocked quartz grains in breccia samples from the Stac Fada Member. (a) Large toasted quartz grain with the typical orange-brown to grayish-reddish brown appearance (sample 012b). (b) Quartz grain with one prominent set of c(0001) planar fractures (PF) (sample 001b). (c) Quartz grain containing two decorated PDF sets with $\omega\{10 \overline{1} 3\}$-equivalent orientations (sample 010b). (d) Small quartz grain with two sets of decorated PDFs; both PDF sets with $\omega\{10 \overline{1} 3\}$-equivalent orientations (sample 004a). (e) Highly shocked quartz grain with three PDF sets, with $\omega\{10 \overline{1} 3\}-,\{10 \overline{1} 4\}-$, and $\omega^{\prime}\{$ $01 \overline{1} 3\}$-equivalent orientations (sample 002b). (f) Quartz grain showing one prominent decorated PDF set with $\omega\{10 \overline{1} 3\}$-equivalent orientation. Note that another PDF set $\left(^{*}\right)$, with $\pi\{10 \overline{1} 2\}$ equivalent orientation, is visible in this grain under U-stage microscope (sample 004a). 


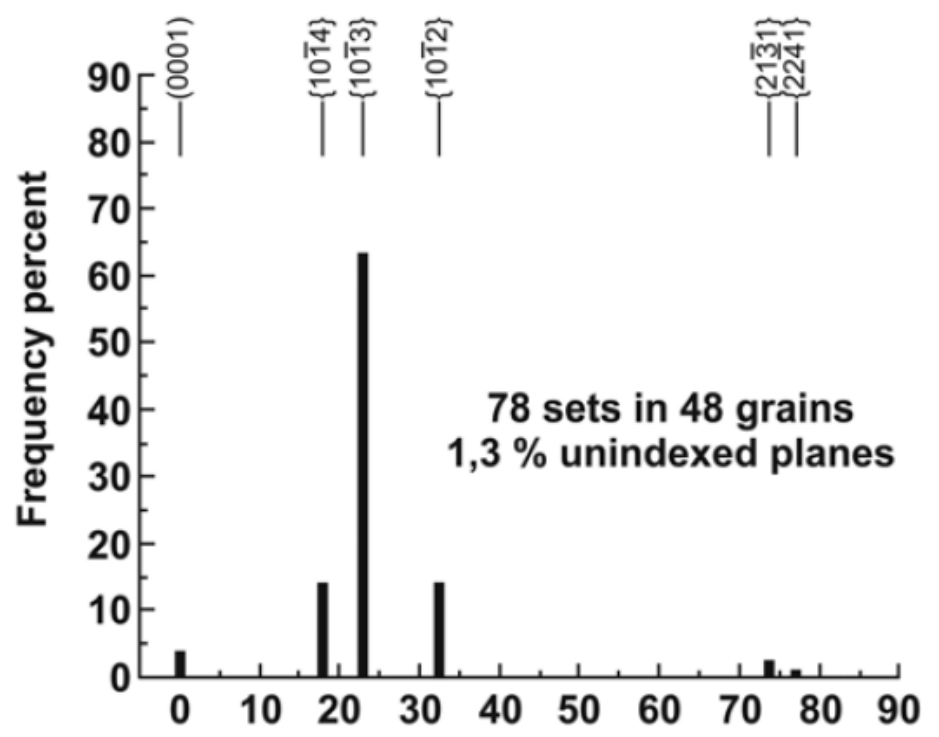

Angle between c-axis and poles to PDF (degrees)

Fig. 8. Histogram of the absolute frequency percent of indexed PDFs in quartz grains from Stac Fada breccia samples using the Automated Numerical Index Executor (ANIE) program (with the average value of measurements and a $5^{\circ}$ error; see Huber et al., 2011) for the indexing. Note that PDF planes that fall into the overlap zone between $\{10 \overline{1} 4\}$ and $\{10 \overline{1} 3\}$ crystallographic orientations (see Table 3 ) are considered as $\{10 \overline{1} 3\}$ orientations in this figure, as suggested by (Ferrière et al. 2009a). 